\title{
DOPUSZCZALNOŚĆ USTALENIA ŚRODOWISKOWYCH UWARUNKOWAŃ DLA ISTNIEJĄCEJ INWESTYCJI W ORZECZNICTWIE SĄDÓW ADMINISTRACYJNYCH
}

Środowisko i jego ochrona jest ważnym elementem wielu orzeczeń sądów administracyjnych. W ostatnich latach ilość tego typu spraw stopniowo wzrasta. Wiąże się to z wprowadzaniem do polskiego ustawodawstwa nowych, zharmonizowanych regulacji europejskich dotyczących ochrony środowiska. Implementacja dyrektyw wiąże się jednak z trudnym procesem dostosowywania przyjmowanych unormowań do instytucji ugruntowanych już w polskim systemie prawa. Dotyczy to zwłaszcza procesu inwestycyjnego, gdzie prawo unijne wymusiło wprowadzenie dodatkowych procedur dotyczących ocen oddziaływania przedsięwzięć na środowisko. Przegląd orzecznictwa sądowoadmini-

* Doktor nauk prawnych, Europejska Wyższa Szkoła Prawa i Administracji (adiunkt), Kancelaria Radców Prawnych s.c. dr K. Szuma, H. Zambrowicz-Rybarczyk w Poznaniu.

** Magister prawa, WSA w Poznaniu. 
stracyjnego prowadzi do wniosku, że pomimo upływu trzech lat od wejścia w życie ustawy z dnia 3 października 2008 r. o udostępnianiu informacji o środowisku i jego ochronie, udziale społeczeństwa w ochronie środowiska oraz o ocenach oddziaływania na środowisko ${ }^{1}$ pewne zagadnienia związane z współfunkcjonowaniem procedur inwestycyjnych (budowlanych) i procedur określonych w tej ustawie nadal pozostają kontrowersyjne.

Przykładem takiego zagadnienia jest kwestia dopuszczalności prowadzenia postępowania i wydania decyzji w sprawie ustalenia środowiskowych uwarunkowań dla inwestora ubiegającego się o legalizację istniejącej już inwestycji. Kwestia ta nie została definitywnie rozstrzygnięta przez ustawodawcę, co powoduje istotne problemy praktyczne.

W sprawach tego rodzaju trzeba zwrócić uwagę na treść art. 71 ust. 1 w zw. z 71 ust. 2 ustawy ooś. Zgodnie z tymi przepisami: „1. Decyzja o środowiskowych uwarunkowaniach określa środowiskowe uwarunkowania realizacji przedsięwzięcia. 2. Uzyskanie decyzji o środowiskowych uwarunkowaniach jest wymagane dla planowanych: 1) przedsięwzięć mogących zawsze znacząco oddziaływać na środowisko; 2) przedsięwzięć mogących potencjalnie znacząco oddziaływać na środowisko". Trzeba też wskazać na przepisy art. 72 ust. 1 pkt 1 i 3 ustawy ooś, które stanowią, iż wydanie decyzji o środowiskowych uwarunkowaniach następuje przed uzyskaniem: „decyzji o pozwoleniu na budowę, decyzji o zatwierdzeniu projektu budowlanego, decyzji o pozwoleniu na wznowienie robót budowlanych oraz decyzji o pozwoleniu na zmianę sposobu użytkowania obiektu budowlanego lub jego części - wydawanych na podstawie ustawy z dnia 7 lipca 1994 r. - Prawo budowlane (Dz. U. z 2006 r. Nr 156, poz. 1118, z późn. zm.)” (pkt 1), a także „decyzji o warunkach zabudowy i zagospodarowania terenu - wydawanej na podstawie ustawy z dnia 27 marca 2003 r. o planowaniu i zagospodarowaniu przestrzennym" (pkt 3).

Użyte przez ustawodawcę sformułowanie, iż decyzja o środowiskowych uwarunkowaniach wymagana jest dla „planowa-

1 Dz. U. z 2008 r. Nr 199, poz. 1227 ze zm.; powoływana dalej jako ustawa ooś.

PRIEELAD PRAWA OCHRONY ŚRODOWISKA 
nych przedsięwzięć" spowodowała, że w praktyce administracyjnej często uznaje się, że rozstrzygnięciem tym można określać środowiskowe uwarunkowania jedynie dla przedsięwzięcia nieistniejącego. W związku z tym mając na uwadze fakt, że postępowanie miałoby dotyczyć instalacji już istniejącej (legalizowanej), która nie podlega modyfikacjom, niemożliwe jest określenie uwarunkowań realizacji przedsięwzięcia, gdyż przedsięwzięcie jest już zrealizowane. Organy podnoszą ponadto, iż w myśl art. 71 ust. 2 ustawy ooś uzyskanie decyzji o środowiskowych uwarunkowaniach jest wymagane dla przedsięwzięć planowanych, a instalacja, którą dany podmiot chce legalizować, nie jest przedsięwzięciem planowanym, dlatego niemożliwe jest wydanie decyzji o środowiskowych uwarunkowaniach ${ }^{2}$. W związku $\mathrm{z}$ taką argumentacją organy niekiedy odmawiają prowadzenia postępowania $\mathrm{w}$ sprawie środowiskowych uwarunkowań dla przedsięwzięcia legalizowanego.

W orzecznictwie sądów administracyjnych wyrażane jest w tej mierze inne stanowisko. Należy wskazać zwłaszcza na wyrok Naczelnego Sądu Administracyjnego z dnia 9 kwietnia 2009 r. o sygn. II OSK 536/08³ , w którym Sąd stwierdził: „gdyby bowiem podzielić pogląd zaprezentowany w tej mierze w skardze kasacyjnej" (że nie można wydać decyzji o środowiskowych uwarunkowaniach dla legalizowanej inwestycji - przyp. aut.), „to inwestor samowolnie realizujący określone przedsięwzięcie inwestycyjne, legalizujący je, oczywiście o ile byłoby to możliwe w świetle obowiązującego prawa, mógłby skutecznie <ominąć> obowiązek sporządzenia przedmiotowego raportu, przecząc systemowej i celowościowej wykładni stosownych przepisów".

W powołanej wyżej sprawie organ pierwszej instancji podał, że w dniu 3 kwietnia 2006 r. strona wystąpiła o wydanie decyzji o środowiskowych uwarunkowaniach. „Zgodnie z postanowieniem Państwowego Powiatowego Inspektora Sanitarnego w Bochni z dnia 2 maja 2006 r. oraz opinią Starosty Powiatu

2 Interpretacja wewnętrzna Generalnego Dyrektora Ochrony Środowiska nr DOOŚ-542/2477/10/JSz-76, niepubl.

3 Publ. Centralna Baza Orzeczeń Sądów Administracyjnych: orzeczenia. nsa.gov.pl. 
Bocheńskiego z dnia 19 maja 2006 r. przyjęto, iż przedmiotowe przedsięwzięcie wymaga opracowania raportu oddziaływania na środowisko". Na postanowienie organu odwoławczego strona wniosła skargę do sądu administracyjnego wnosząc o umorzenie postępowania prowadzonego przez Burmistrza Miasta Bochni jako bezprzedmiotowego. Skarżący wskazali, że budowa wjazdu i zjazdu ma służyć obsłudze stacji paliw, na której budowę zostało uchylone pozwolenie. W sprawie wybudowanych już zjazdów i wjazdów toczy się postępowanie przed organami nadzoru budowlanego i nie można wydać postanowienia zobowiązującego do opracowania raportu o oddziaływaniu na środowisko. Wojewódzki Sąd Administracyjny w Krakowie uznał skargę za niezasadną. Stwierdził, że „stosownie do regulacji art. 51 ust. 1 pkt 2 i ust. 2 Prawa ochrony środowiska oraz $\S 3$ ust. 1 pkt 56 i 72a i ust. 2 rozporządzenia Rady Ministrów z dnia 9 listopada 2004 r. w sprawie określenia rodzajów przedsięwzięć mogących znacząco oddziaływać na środowisko oraz szczegółowych uwarunkowań związanych z kwalifikowaniem przedsięwzięcia do sporządzenia raportu o oddziaływaniu na środowisko (Dz. U. Nr 257, poz. 2573 ze zm.) należało w niniejszej sprawie wydać postanowienie zobowiązujące do opracowania raportu o oddziaływaniu na środowisko, w oparciu o który zostanie wydana przez Burmistrza Bochni decyzja o środowiskowych uwarunkowaniach zgody na realizację przedsięwzięcia".

Od wyroku Wojewódzkiego Sądu Administracyjnego w Krakowie strona złożyła skargę kasacyjną, wnosząc o jego uchylenie w całości i przekazanie sprawy do ponownego rozpoznania sądowi pierwszej instancji. Jako zarzut naruszenia prawa materialnego wskazano m. in. na art. 51 ust. 1 pkt 2 Prawa ochrony środowiska i art. 32 ust. 1 oraz art. 33 ust. 1 ustawy z dnia 7 lipca 1994 r. - Prawo budowlane (Dz. U. z 2006 r. Nr 156, poz. 1118 ze zm.) „[...] - poprzez przyjęcie, że dopuszczalne jest wydanie postanowienia w sprawie ustalenia obowiązku sporządzenia raportu dla przedsięwzięcia już zrealizowanego oraz że dopuszczalne jest wydanie postanowienia w sprawie ustalenia obowiązku sporządzenia raportu dla przedsięwzięcia określonego jako budowa wjazdu i wyjazdu na drodze wojewódzkiej. Strona wskazała jeszcze kilka innych zarzutów, jednak nie zostały tutaj przytoczone 
z uwagi na fakt, iż nie mają znaczenia dla wskazanego na początku opracowania problemu. Podkreślenia wymaga fakt, iż skarga kasacyjna nie odniosła zamierzonego skutku. Naczelny Sąd Administracyjny stwierdził bowiem, że „Co do zaś zarzutu naruszenia przepisu art. 51 ust. 1 pkt 2 Prawa ochrony środowiska poprzez przyjęcie przez Sąd pierwszej instancji, że dopuszczalne jest sporządzenie raportu dla zrealizowanego przedsięwzięcia inwestycyjnego, to i ten zarzut nie mógłby odnieść zamierzonych skutków. Gdyby bowiem podzielić pogląd zaprezentowany w tej mierze w skardze kasacyjnej to inwestor samowolnie realizujący określone przedsięwzięcie inwestycyjne, legalizujący je, oczywiście o ile byłoby to możliwe w świetle obowiązującego prawa, mógłby skutecznie <ominąć> obowiązek sporządzenia przedmiotowego raportu, przecząc systemowej i celowościowej wykładni stosownych przepisów".

Dodatkowo Wojewódzki Sąd Administracyjny w Opolu (sygn. II SA/Op 170/08), w tezowanym wyroku z dnia 3 listopada 2008 r. wskazal, iż „Skoro przy samowoli budowlanej polegającej na istotnym odstąpieniu od zatwierdzonego projektu budowlanego lub innych warunków pozwolenia na budowę wymagana jest decyzja o środowiskowych uwarunkowaniach, poprzedzająca pozwolenie na wznowienie robót, to przy legalizacji samowoli budowlanej bez pozwolenia (z uwagi na stwierdzenie jego nieważności), nie może zostać pominięta także wspomniana decyzja środowiskowa. Przyjęcie innego stanowiska w sprawie, co do wymogu uzyskania decyzji o środowiskowych uwarunkowaniach, spowodowałoby stawianie w korzystniejszej sytuacji sprawców samowoli budowlanej bez pozwolenia ( $w$ wyniku stwierdzenia nieważności), od tych, którzy realizują inwestycję na podstawie pozwolenia (dokonując istotnych odstępstw)".

W omawianej sprawie Powiatowy Inspektor Nadzoru Budowlanego nałożył obowiązek zamurowania otworu drzwiowego prowadzącego do istniejącej hali, znajdującego się w ścianie rozbudowanej części budynku. Decyzja ta została wydana na podstawie art. 51 ust. 1 pkt 2 ustawy z dnia 7 lipca 1994 r. Prawo budowlane (Dz. U. z 2006 r. Nr 156, poz. 1116 ze zm.). W motywach rozstrzygnięcia podano, że inwestorzy rozpoczęli roboty budowlane w zakładzie, na podstawie ostatecznej decy- 
zji o pozwoleniu na budowę z dnia 18 stycznia 2002 r., w stosunku do której w dniu 8 stycznia 2003 r. stwierdzono nieważność. W efekcie Powiatowy Inspektor Nadzoru Budowlanego wstrzymał roboty budowlane. Następnie dniu 10 czerwca 2003 r. Powiatowy Inspektor wydał - na zasadzie art. 51 ust. 1a - pozwolenie na wznowienie robót budowlanych, które w wyniku złożonego odwołania, Wojewódzki Inspektor Nadzoru Budowlanego utrzymał w mocy. W wyniku wniesienia skargi na tę decyzję, Wojewódzki Sąd Administracyjny w Opolu wyrokiem z dnia 20 lipca 2006 r., sygn. akt II SA/Op 98/06 uchylił obie decyzje $\mathrm{w}$ przedmiocie pozwolenia na wznowienie robót oraz decyzję z dnia 24 stycznia 2003 r. zobowiązującą inwestorów do dostarczenia dokumentów. Następnie wydano nową, podobną decyzję. Odwołanie wniosła W. K., uznając tę decyzje za krzywdząca dla niej i żądała zaprzestania prowadzenia działalności przez sprawców samowoli. Podniosła, że przepisy prawa miejscowego (plan zagospodarowania) nie pozwalają na funkcjonowanie ich zakładu w obecnym miejscu. Podkreśliła, że w spornej sprawie uchylone zostały wszystkie decyzje dotyczące legalizacji bezprawnej inwestycji. Dodała, że „w obiegu nie istnieje żadna decyzja dotycząca zakładu".

W wyniku rozpatrzenia odwołania Wojewódzki Inspektor Nadzoru Budowlanego, uznał zarzuty odwołania za bezpodstawne i postanowił, na zasadzie art. $138 \S 1$ pkt 1 K.p.a. utrzymać w mocy zaskarżoną decyzję. Organ odwoławczy na wstępie stwierdzil, iż podziela stanowisko Powiatowego Inspektora Nadzoru Budowlanego wyrażone w zaskarżonej decyzji. Odnosząc się do zarzutów odwołania podniósł, iż w omawianej sprawie przesłanką prowadzonego postępowania z zakresu nadzoru budowlanego był fakt prowadzenia robót budowlanych bez wymaganego pozwolenia na budowę (stwierdzono bowiem nieważność wcześniej udzielonego pozwolenia). Jest to sytuacja inna niż określona w art. 48 Prawa budowlanego. Analizując działania podejmowane przez inwestorów w toku procesu budowlanego, a także powołując się na poglądy judykatury i piśmiennictwa organ podniósł, że inwestorowi nie można uczynić zarzutu dopuszczenia się samowoli budowlanej w rozumieniu art. 48 Prawa budowlanego, gdyż w dacie rozpoczęcia robót 
budowlanych legitymował się ostateczną decyzją o pozwoleniu na budowę.

Skargę na powyższą decyzję złożyła W. K. Sąd I instancji stwierdzil, że stan prawny robót budowlanych, których dotyczy kontrolowana decyzja jest oczywisty, bowiem wykonane roboty stanowią samowolę budowlaną określoną w art. 51 Prawa budowlanego, gdyż inwestor rozpoczął roboty budowlane na podstawie ostatecznej decyzji o pozwoleniu na budowę z dnia 18 stycznia 2002 r., z jednoczesnym zatwierdzeniem projektu budowlanego dotyczącego rozbudowy i modernizacji zakładu przetwórstwa mięsnego z ubojnią wraz z przyłączami. W trakcie realizacji tej inwestycji wojewoda decyzją z dnia 8 stycznia 2003 r. stwierdził nieważność powyższego pozwolenia na budowę, a zatem należy przyjąć, że inwestor zrealizował część robót w okresie ważności pozwolenia na budowę, pozostałe roboty zostały wykonane bez takiego pozwolenia. Sąd uznał, że „przystępując do legalizacji samowoli budowlanej, organy nadzoru budowlanego w pierwszej kolejności zobowiązane są zbadać, czy dochowane zostały wymogi stawiane spornej inwestycji przez obowiązujący plan, a przypadku braku planu w dacie podjęcia działań legalizacyjnych, czy te poprzednie plany - $\mathrm{w}$ trakcie realizacji robót - nie sprzeciwiały się tej inwestycji. Takie ustalenia powinny odnosić się do już sfinalizowanych robót. Dlatego też, nie do przyjęcia byłoby stanowisko, aby przy legalizacji, organy nadzoru budowlanego nie były zobowiązane do zbadania zgodności zrealizowanej inwestycji z ładem przestrzennym. Podobne stanowisko, należy przyjąć także w zakresie regulacji i wymogów dot. ochrony środowiska, skoro w decyzji stwierdzającej nieważność pozwolenia wskazano, iż zostało ono wydane $\mathrm{z}$ pominięciem procedury wynikającej z art. 12-17 i art. 25 ust. 2 ustawy z dnia 9 listopada 2000 r. o dostępie do informacji o środowisku i jego ochronie oraz o ocenach oddziaływania na środowisko (Dz. U. Nr 109, poz. 1157), co powoduje nieważność z mocy prawa. Skoro proces legalizacji samowoli budowlanej zastępuje niejako proces pozwolenia na budowę, aby można dokonanie oceny samowolnie wykonanych robót, niezbędnym staje się dokonać oceny zgodności tych robót z prawem, a zatem ich zgodności również z przepisami Prawa ochrony środowiska. Jeżeli roboty te dotyczą inwestycji znacząco 
oddziaływującej na środowisko, to wówczas wymagana będzie decyzja o środowiskowych uwarunkowaniach, o której mowa w art. 46 ust. 4 pkt 2 Prawa ochrony środowiska. Z przepisu tego wynika, że decyzja ta wymagana jest przed uzyskaniem decyzji o pozwoleniu na wznowienie robót budowlanych. Skoro przy samowoli budowlanej polegającej na istotnym odstąpieniu od zatwierdzonego projektu budowlanego lub innych warunków pozwolenia na budowę wymagana jest decyzja o środowiskowych uwarunkowaniach, poprzedzająca pozwolenie na wznowienie robót, to przy legalizacji samowoli budowlanej bez pozwolenia (z uwagi na stwierdzenie jego nieważności), nie może zostać pominięta także wspomniana decyzja środowiskowa. Przyjęcie innego stanowiska w sprawie, co do wymogu uzyskania decyzji o środowiskowych uwarunkowaniach, spowodowałoby stawianie w korzystniejszej sytuacji sprawców samowoli budowlanej bez pozwolenia (w wyniku stwierdzenia nieważności), od tych, którzy realizują inwestycję na podstawie pozwolenia (dokonując istotnych odstępstw). Omawiana decyzja środowiskowa, pozwoli organowi nadzoru budowlanego ocenić stan wykonanych samowolnie robót budowlanych pod względem zgodności z prawem. Powyższego stanowiska nie może niweczyć okoliczność, że w podjętych działaniach zmierzających do wydania decyzji $\mathrm{z}$ art. 51 ust. 1 pkt $2 \mathrm{w}$ zw. $\mathrm{z}$ art. 51 ust. 7 Prawa budowlanego nie występuje przypadek, uzyskania przez inwestora, pozwolenia na wznowienie robót budowlanych. Skoro zaś, w sytuacji gdy roboty są zakończone, do wydania pozwolenia na wznowienie robót nie dochodzi, stąd konieczne jest przeprowadzenie postępowania $z$ art. 46 ust. 4 pkt 2 Prawa ochrony środowiska, już na etapie orzekania w oparciu o art. 51 ust. 1 pkt 2 Prawa budowlanego. Inwestorowi nie powinno się stawiać mniejszych wymogów niż w przypadku pozwolenia na budowę. Podobne stanowisko, aczkolwiek dotyczące innego przedmiotu sprawy, zostało zajęte w uzasadnieniu wyroku WSA w Gliwicach z dnia 19 lipca 2006 r., sygn. akt II SA/GL 671/05 niepubl.”.

Ponadto w innym orzeczeniu z dnia 25 kwietnia 2007 r. (sygn. II SA/Łd 82/07) Wojewódzki Sąd Administracyjny w Łodzi stwierdził, że w związku z zamiarem legalizacji wybudowanego 3/2011 już obiektu „konieczne jest przedłożenie szeregu dokumentów, 
projektów, uzgodnień, których analiza pozwoli organom nadzoru budowlanego sprawdzić zgodność wybudowanej inwestycji z obowiązującymi przepisami. Owszem w chwili zakończenia budowy [...] nie jest już możliwie, nie jest również zasadne, staranie się o uzyskanie decyzji o pozwoleniu na budowę [...]. Jednakże jest możliwe przeprowadzenie postępowania legalizacyjnego, do pomyślnego zakończenia którego jest konieczne zbadanie zgodności z decyzją o środowiskowych uwarunkowaniach zgody. Nie można zatem uznać, iż wydanie decyzji o środowiskowych uwarunkowaniach realizacji inwestycji było nieuzasadnione. Nie możemy [...] mówić o bezprzedmiotowości tego postępowania w sytuacji, gdy ustawa z dnia 27 kwietnia 2001 r. Prawo ochrony środowiska przewiduje wydawanie przedmiotowej decyzji m.in. przed uzyskaniem pozwolenia na budowę przedsięwzięcia mogącego znacząco oddziaływać na środowisko lub przed uzyskaniem pozwolenia wodnoprawnego, zgłoszenia w zakresie zmiany sposobu użytkowania. Trzeba jednocześnie wyraźnie wskazać, iż Ustawa ta nie wskazuje również przepisu, z którego wynikałoby, iż nie jest możliwe wydanie decyzji o środowiskowych uwarunkowaniach [...] już po realizacji inwestycji objętej takim wnioskiem. Reasumując nie możemy mówić o bezprzedmiotowości postępowania, która uzasadniałaby jego umorzenie, a co za tym o rażącym naruszeniu prawa. Wybudowanie studni nie przekreśla bowiem prawa inwestora do otrzymania decyzji o środowiskowych uwarunkowaniach zgody na realizację inwestycji. Brak przepisu prawa sankcjonującego taką sytuację powoduje, że nie można mówić o obowiązku umorzenia postępowania prowadzonego w sposób odmienny niż oczekuje strona".

W innym orzeczeniu Wojewódzki Sąd Administracyjny we Wrocławiu (wyrok z dnia 6 grudnia 2007 r. - sygn. II SA/Wr 132/07) stwierdzil, że z punktu widzenia ochrony wymagań ochrony środowiska nie ma znaczenia czy inwestor ma uzyskać pozwolenie na budowę, czy też dąży do legalizacji popełnionej samowoli budowlanej. „Aby prowadzić którekolwiek z tych postępowań musi legitymować się decyzją określającą środowiskowe uwarunkowania zgody na realizację przedsięwzięcia".

W wyroku z dnia 3 lutego 2010 r. o sygn. akt II GSK 6/10 Naczelny Sąd Administracyjny odniósł się do kwestii możli- 
wości prowadzenia postępowania w sprawie środowiskowych uwarunkowań dla inwestycji istniejącej na tle ustawy ooś. Choć orzeczenie to nie zapadło $\mathrm{w}$ sprawie $\mathrm{z}$ zakresu ochrony środowiska a z zakresu funduszy unijnych, to jednak zagadnienie to zostało szeroko przeanalizowane (przeprowadzenie oceny oddziaływania przedsięwzięcia na środowisko miało znaczenie dla dopuszczalności dofinansowania projektu z budżetu Unii Europejskiej). W uzasadnieniu Naczelny Sąd Administracyjny stwierdził, że „Rozpoczęcie realizacji inwestycji, a nawet zrealizowanie inwestycji, nie czyni bezprzedmiotowym postępowania w sprawie środowiskowych uwarunkowań zgody na określoną inwestycję. To, że organ właściwy w sprawach o pozwolenie na budowę może wydać decyzję o pozwoleniu na budowę, jeżeli są spełnione wszystkie warunki do wydania takiej decyzji, w tym wymagania $\mathrm{w}$ zakresie ochrony środowiska, nie jest równoznaczne z tym, że po wydaniu takiej decyzji wyłączona jest jakakolwiek możliwość przeprowadzenia oceny oddziaływania inwestycji na środowisko [...]. Zasadnicze zagadnienie $\mathrm{w}$ tej sprawie sprowadza się - z uwagi na zarzuty podniesione w skardze kasacyjnej - do oceny, czy po wydaniu pozwolenia na budowę i rozpoczęciu budowy, na etapie prowadzonego na podstawie ustawy z dnia 6 grudnia 2006 r. o zasadach prowadzenia polityki rozwoju (tekst jedn.: Dz. U. z 2009 r. Nr 84, poz. 712) postępowania o dofinansowanie projektu, może być przeprowadzona ocena oddziaływania inwestycji na środowisko. W tym zakresie organ zajął stanowisko, które podzielił Sąd pierwszej instancji, że z uwagi na »uprzednią« wadliwość co do oceny oddziaływania na środowisko i stopień zaawansowania inwestycji, brak jest na obecnym etapie możliwości przeprowadzenia takich działań, które w odniesieniu do wymagań środowiskowych skutkowałyby stwierdzeniem zgodności inwestycji z dyrektywą Rady nr 85/337/EWG, co oznacza, że w tej sprawie nie było możliwości warunkowego dopuszczenia projektu do dalszej oceny, gdyż możliwe jest to wyłącznie w odniesieniu do inwestycji planowanych, a więc takich, co do których istnieją zamierzenia ich powstania w przyszłości, które nie znajdują się jeszcze w stadium realizacji, gdy organ może wskazać sposób 3/2011 działania niezbędny do zapewnienia zgodności planowanych 
przedsięwzięć z wymaganiami dyrektywy. Inaczej mówiąc, przeprowadzenia oceny oddziaływania na środowisko dokonuje się przed udzieleniem pozwolenia na budowę, co na obecnym etapie realizacji inwestycji nie może nastąpić".

Odnosząc się do takiego stanowiska sądu pierwszej instancji Naczelny Sądu Administracyjny podniósł jednak, że nie można ograniczać się do przyjmowania literalnego brzmienia art. 59 ust. 1 ustawy ooś, który to przepis wskazuje, że przeprowadzenia oceny oddziaływania przedsięwzięcia na środowisko wymaga realizacja określonych planowanych przedsięwzięć mogących znacząco oddziaływać na środowisko. Zdaniem Naczelnego Sądu Administracyjnego „trzeba [...] mieć na uwadze, że wykładnia gramatyczna nie jest jedyną metodą interpretacji prawa i bywa, że trzeba sięgać do innych rodzajów wykładni, w tym wykładni systemowej i celowościowej, tak aby wydobyć rzeczywiste znaczenie normy prawnej. Stanowisko takie [...] zostało zaprezentowane w wyroku Naczelnego Sądu Administracyjnego z dnia 26 listopada 2008 r. o sygn. akt II OSK 1481/07 i odnosiło się do wykładni art. 46 ust. 1ustawy z dnia 27 kwietnia 2001 r. Prawo ochrony środowiska (tekst jedn.: Dz. U. z 2006 r. Nr 129, poz. 902 ze zm.), który to przepis warunkował realizację planowanych przedsięwzięć mogących znacząco oddziaływać na środowisko od uprzedniego uzyskania decyzji o środowiskowych uwarunkowaniach zgody na realizację przedsięwzięcia. W uzasadnieniu tego wyroku przyjęto stanowisko, iż rozpoczęcie realizacji inwestycji, a nawet zrealizowanie inwestycji, nie czyni bezprzedmiotowym postępowania $\mathrm{w}$ sprawie środowiskowych uwarunkowań zgody na określoną inwestycję".

Wskazując motywy uchylenia wyroku sądu pierwszej instancji Naczelny Sądu Administracyjny podkreślił też, że nie wskazano w uzasadnieniu zaskarżonego wyroku z jakich przepisów rangi ustawowej wynika to, że po wydaniu pozwolenia na budowę i rozpoczęciu budowy nie jest możliwe dokonanie oceny oddziaływania inwestycji na środowisko. Dodał, iż to, że dyrektywa Rady i ustawa ooś nakładają obowiązek przeprowadzenia oceny oddziaływania określonego przedsięwzięcia na środowisko przed uzyskaniem decyzji o pozwoleniu na budowę nie oznacza, iż tym samym wyłączone jest dokonywanie takiej 
oceny po uzyskaniu pozwolenia na budowę. „To, że organ właściwy w sprawach o pozwolenie na budowę może wydać decyzję o pozwoleniu na budowę jeżeli są spełnione wszystkie warunki do wydania takiej decyzji, w tym wymagania w zakresie ochrony środowiska, nie jest równoznaczne z tym, że po wydaniu takiej decyzji wyłączona jest jakakolwiek możliwość przeprowadzenia oceny oddziaływania inwestycji na środowisko. Ocena w tym zakresie wymaga odniesienia się nie tylko do przepisów ustaw z zakresu ochrony środowiska, ale także przepisów ustawy z dnia 7 lipca 1994 r. Prawo budowlane".

Wskazać należy, iż jednak niektórzy przedstawiciele doktryny krytycznie odnoszą się do stanowiska prezentowanego przez Naczelny Sądu Administracyjny w powołanym wyżej wyroku. Wskazują, iż „Ustawa OOŚ [z 2008 r. o udostępnianiu informacji o środowisku i jego ochronie, udziale społeczeństwa w ochronie środowiska oraz o ocenach oddziaływania na środowisko] w art. 59 i 72 ust. 1 przesądza, że ocena oddziaływania na środowisko ma być przeprowadzona przed wydaniem decyzji zezwalających na realizację przedsięwzięcia (np. pozwolenia na budowę) i przed rozpoczęciem tej realizacji. [...] Wydanie decyzji środowiskowej (i tym samym przeprowadzenie OOŚ lub tylko etapu selekcji) po uzyskaniu pozwolenia na realizację przedsięwzięcia, a tym bardziej po jego zrealizowaniu, jest sprzeczne z [...] przepisami dyrektywy 85/337 i ustawy OOŚ [ z 2008 r. o udostępnianiu informacji o środowisku i jego ochronie, udziale społeczeństwa w ochronie środowiska oraz o ocenach oddziaływania na środowisko]"4.

Jednak naszym zdaniem, mając na uwadze przytoczone orzeczenia, należy również przyjrzeć się bliżej art. 72 ust. 1 pkt 1 ustawy ooś oraz przepisom Prawa budowlanego. Zgodnie z tym przepisem decyzję o środowiskowych uwarunkowaniach wydaje się przed uzyskaniem np. decyzji o zatwierdzeniu projektu budowlanego i decyzji o wznowieniu robót budowlanych. Decyzje te - wydawane na podstawie art. 49 ust. 4 pkt 1 i 2 ustawy z dnia

4 M. Bar, J. Jendrośka, Glosa do wyroku NSA z dnia 3 lutego 2010 r., II GSK 6/10, „Prawo i Środowisko” 2010, nr 4, s. 102 i n. 
7 lipca 1994 r. Prawo budowlane ${ }^{5}$ wieńczą właśnie postępowanie legalizacyjne (art. 48 ust. 2 i art. 49 Prawa budowlanego). Co więcej, art. 49 ust. 4a Prawa budowlanego stanowi, że decyzje o zatwierdzeniu projektu budowlanego i pozwoleniu na wznowienie robót oraz o zatwierdzeniu projektu budowlanego (dla zakończonej budowy) „mogą być wydane po uprzednim przeprowadzeniu oceny oddziaływania przedsięwzięcia na środowisko albo oceny oddziaływania przedsięwzięcia na obszar Natura 2000, jeżeli jest ona wymagana przepisami ustawy z dnia 3 października 2008 r. o udostępnianiu informacji o środowisku i jego ochronie, udziale społeczeństwa w ochronie środowiska oraz o ocenach oddziaływania na środowisko". Z powyższego przepisu należy wywnioskować, że ustawodawca nie tylko przewidział, ale nawet nałożył obowiązek wydania decyzji o środowiskowych uwarunkowaniach przed decyzjami kończącymi postępowanie legalizacyjne dla istniejących inwestycji.

W świetle powyższego wydaje się, że pojęcie „planowane przedsięwzięcie” w znaczeniu nadanym mu w ustawie ooś należy interpretować nie wyłącznie literalnie, to jest nie jako przedsięwzięcie „dopiero planowane” czyli „nieistniejące”, „mające powstać”, ale jako „przedsięwzięcie docelowo zamierzone przez inwestora". W związku z tym nie powinno mieć znaczenia dla organu prowadzącego postępowanie w sprawie środowiskowych uwarunkowań czy na działce inwestora znajduje się jakaś inwestycja. Rolą organu jest bowiem określenie warunków środowiskowych dla zamierzenia wskazanego we wniosku, a nie kontrola istniejącego sposobu zagospodarowania działki.

Na poparcie powyższego stanowiska warto powołać także poważne kontrowersje jakie niegdyś powstały na tle interpretacji art. 59 ustawy o planowaniu i zagospodarowaniu przestrzennym. Przepis ten stanowi, że „Zmiana zagospodarowania terenu w przypadku braku planu miejscowego, polegająca na budowie obiektu budowlanego lub wykonaniu innych robót budowlanych, a także zmiana sposobu użytkowania obiektu budowlanego lub jego części [...] wymaga ustalenia, w drodze decyzji warunków 
zabudowy". W orzecznictwie sądowoadministracyjnym konsekwentnie przyjmowano, że przepis ten wyłącza możliwość ustalenia warunków zabudowy dla istniejącej inwestycji ${ }^{6}$. Stanowisko sądów administracyjnych radykalnie zmieniło się w wyniku wyroku Trybunału Konstytucyjnego z dnia 20 grudnia 2007 r. sygn. akt P 37/067. W orzeczeniu tym Trybunał zakwestionował konstytucyjność art. 48 ust. 2 pkt 1 lit. b oraz art. 48 ust. 3 pkt 1 Prawa budowlanego ${ }^{8}$, w zakresie $\mathrm{w}$ jakim przepisy te wymagały od inwestora zainteresowanego legalizacją samowoli budowlanej dostarczenia decyzji o ustaleniu warunków zabudowy ostatecznej „w dniu wszczęcia postępowania” legalizacyjnego. Najistotniejsze jest jednak to, że w omawianym wyroku Trybunał przesądził, że „Decydujące znaczenie w procesie legalizacji samowoli (również legalizacji prowadzonej w związku z wszczęciem postępowania rozbiórkowego) winno mieć ustalenie, że obiekt wybudowany bez pozwolenia na budowę nie narusza przepisów prawa - w tym regulujących kwestie planowania i zagospodarowania przestrzennego. Powinna zatem istnieć możliwość dokonania takiego ustalenia również po wszczęciu postępowania rozbiórkowego, bo nie do pogodzenia z zasadami konstytucyjnymi jest orzekanie rozbiórki obiektu budowlanego, mimo że inwestorzy wykazali jego zgodność z przepisami o planowaniu i zagospodarowaniu przestrzennym, uzyskując ostateczną decyzję o warunkach zabudowy już w trakcie postępowania rozbiórkowego".

Cytowany wyrok Trybunału Konstytucyjnego, choć zapadł w odniesieniu do przepisów prawa budowlanego, ma także znaczenie dla ustalenia dopuszczalności prowadzenia postępowania w sprawie ustalenia uwarunkowań środowiskowych dla legalizowanej inwestycji. Należy bowiem zwrócić uwagę, że skoro zgodnie z tym orzeczeniem istotą postępowania legalizacyjnego jest

6 Zob. Wyrok Naczelnego Sądu Administracyjnego z dnia 19 listopada 2008 r. sygn. akt II OSK 1401/07, publ. Centralna Baza Orzeczeń Sądów Administracyjnych: orzeczenia.nsa.gov.pl, wyrok Wojewódzkiego Sądu Administracyjnego w Warszawie z dnia 15 stycznia 2007 r. sygn. akt IV SA/Wa 2018/06, publ. Lex nr 310877, wyrok Wojewódzkiego Sądu Administracyjnego w Warszawie z dnia 1 lipca 2005 r. sygn. akt IV SA/Wa 185/05, publ. Lex nr 190612).

7 Publ. Dz. U. z 2007 r. Nr 247, poz. 1844 oraz OTK-A 2007/11/160.

8 Ówcześnie w brzmieniu: Dz. U. z 2003 r. Nr 207, poz. 2016, ze zm. 
ustalenie zgodności samowolnie wybudowanej inwestycji z przepisami, w tym przez następcze przeprowadzenie postępowania w sprawie warunków zabudowy, to tym bardziej dopuszczalne, a nawet konieczne powinno być poprzedzenie go postępowaniem w sprawie środowiskowych uwarunkowań. Przyjęcie, że decyzji o środowiskowych uwarunkowaniach nie można wydać dla inwestycji legalizowanej de facto niweczyłoby skutki wyroku Trybunału Konstytucyjnego, gdyż bez tej decyzji inwestor nie mógłby uzyskać decyzji o warunkach zabudowy.

Adwersarze poglądu, iż możliwe jest ustalenie środowiskowych uwarunkowań dla inwestycji legalizowanych powołują się także na argument, że w odniesieniu do przedsięwzięcia istniejącego nie ma możliwości jego modyfikacji. Naszym zdaniem jest on zbyt daleko idący. Należy bowiem zwrócić uwagę, że postępowanie naprawcze prowadzone przez organy nadzoru budowlanego jest w pewnym zakresie „elastyczne” i zatwierdzeniu nie musi podlegać wyłącznie projekt budowlany wiernie odzwierciedlający istniejący stan samowolnie wybudowanego obiektu. Jeżeli w celu legalizacji obiektu budowlanego inwestor uzyska decyzję o środowiskowych uwarunkowaniach oraz decyzję o warunkach zabudowy, które wymogą modyfikacje istniejącego już obiektu, to zgodnie z art. 49 ust. 3 Prawa budowlanego organ nadzoru budowlanego będzie uprawniony do nałożenia obowiązku usunięcia nieprawidłowości w tym zakresie pod rygorem orzeczenia rozbiórki obiektu (należy pamiętać też, że decyzja o środowiskowych uwarunkowaniach wiąże organ nadzoru budowlanego w zakresie w jakim rozstrzyga on o zatwierdzeniu projektu budowlanego - art. 86 w zw. z art. 72 ust. 1 pkt 1 ustawy ooś). Z powyższego wynika, że dopuszczenie możliwości wydania decyzji o środowiskowych uwarunkowaniach w odniesieniu do inwestycji legalizowanej nie rodzi zagrożenia ominięcia prawa. Jeżeli bowiem w toku postępowania prowadzonego na podstawie ustawy ooś ustalone zostanie, że przedsięwzięcie będzie mogło być zrealizowane w zmodyfikowanym wariancie w stosunku do przedstawionego przez inwestora (istniejącego), to ten będzie zmuszony do wprowadzenia do legalizowanej inwestycji narzuconych modyfikacji, pod rygorem

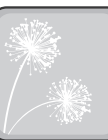


odmowy zatwierdzenia projektu budowlanego ${ }^{9}$. W skrajnym natomiast przypadku, jeżeli postępowanie w sprawie środowiskowych uwarunkowań wykluczy możliwość funkcjonowania inwestycji $\mathrm{w}$ istniejącym kształcie, jej legalizacja nie będzie wtedy możliwa.

Analizując problematykę dopuszczalności przeprowadzenia postępowania $\mathrm{w}$ sprawie środowiskowych uwarunkowań istniejącej inwestycji nie można nie odnieść się także do wyroku Europejskiego Trybunału Sprawiedliwości z dnia 3 lipca 2008 r. nr C-215/06 w sprawie Komisja Wspólnot Europejskich przeciwko Irlandii ${ }^{10}$. W wyroku tym Trybunał stwierdził, iż Irlandia uchybiła zobowiązaniom określonym w art. 2, 4 i 5-10 dyrektywy Rady 85/337/EWG z dnia 27 czerwca 1985 r. w sprawie oceny skutków wywieranych przez niektóre przedsięwzięcia publiczne i prywatne na środowisko naturalne ${ }^{11}$, poprzez nie przyjęcie wymaganych przepisów niezbędnych do zapewnienia, aby przedsięwzięcia objęte dyrektywą zostały - zanim zostaną w całości lub w części wykonane - poddane badaniu mającemu na celu ustalenie, czy istnieje obowiązek przeprowadzenia oceny skutków wywieranych na środowisko, a następnie - jeżeli mogą znacząco oddziaływać na środowisko z powodu ich charakteru, rozmiarów lub lokalizacji - poddane ocenie w odniesieniu do ich skutków zgodnie z art. 5-10 dyrektywy 85/337.

Wstępna analiza powyższego wyroku może prowadzić do wniosku, że Trybunał Sprawiedliwości wykluczył dopuszczalność wdrożenia postępowań w sprawie oceny oddziaływania przedsięwzięcia na środowisko na etapie realizacji albo po zrealizowaniu inwestycji, a przepisy krajowe które dopuszczają możliwość przeprowadzenia takich postępowań w odniesieniu do istniejących inwestycji są niezgodne z dyrektywą 85/337/EWG. Gdy jednak zapoznamy się bliżej z irlandzką ustawą o planowaniu i rozwoju przestrzennym ${ }^{12} \mathrm{w}$ brzmieniu z 2000 r., której prze-

9 Art. 49 ust. 3 Prawa budowlanego w zw. z art. 86 i art. 72 ust. 1 pkt 1 ustawy ooś.

10 Dz. Urz. UE C 260 z dnia 11.10.2008, s. 3, uzasadnienie publ. w bazie curia.europa.eu.

$11 \mathrm{~W}$ jej brzmieniu przed zmianą lub po zmianie przez dyrektywę Rady 97/11/WE z dnia 3 marca 1997 r.

12 Planning and Development Act, 2000, Irish Statute Book No. 30/2000. 
pisy były przedmiotem analizy, okazuje się, że wyrok C-215/06 wcale nie daje podstaw do stawiania tak jednoznacznych tez. Należy zauważyć, że art. 32 (1) lit. b irlandzkiej ustawy o planowaniu i rozwoju przestrzennym dawał inwestorowi generalną możliwość wystąpienia o udzielenie „zatwierdzenia” dla przedsięwzięcia zrealizowanego bez pozwolenia. Z kolei w myśl art. 34 (12) tej ustawy dla przedsięwzięcia takiego udzielano zatwierdzenia (z niezbędnymi modyfikacjami), jeżeli spełniało warunki do uzyskania zezwolenia. Zdaniem Trybunału irlandzkie zatwierdzenia legalizacyjne $\mathrm{w}$ istocie zrównano ze skutkami zwykłych zezwoleń budowlanych, jakie powinny być wydane przed rozpoczęciem realizacji inwestycji. Co więcej, istnienie po stronie inwestora uprawnienia do zatwierdzenia samowolnie zrealizowanego przedsięwzięcia mogło skłaniać władze do niepodejmowania działań w celu wstrzymania albo nawet likwidacji inwestycji objętych zakresem działania i naruszających przepisy dyrektywy 85/337/EWG. Dlatego Trybunał uznał, że „System legalizacji taki jak obowiązujący w Irlandii może [...] skłaniać wykonawców do uchylenia się od weryfikacji, czy planowane przedsięwzięcia spełniają kryteria określone w art. 2 ust. 1 zmienionej dyrektywy 85/337 i w konsekwencji do niepodejmowania kroków niezbędnych do określenia skutków tych przedsięwzięć dla środowiska i ich wcześniejszej oceny ${ }^{13}$ ". Trybunał zauważył też, że takim naruszeniom nie zapobiegał system kar przewidzianych za podjęcie procesu inwestycyjnego bez zezwolenia, który okazał się nieskuteczny.

Ocena polskiego ustawodawstwa z perspektywy wyroku C-215/06 nie daje podstaw do formułowania tak poważnych zarzutów jak te, które Trybunał skierował pod adresem ustawodawcy irlandzkiego. Po pierwsze podnieść należy, że polskie Prawo budowlane nie przewiduje wnioskowego systemu legalizacji, jak miało to miejsce w Irlandii. Postępowanie legalizacyjne następuje zawsze ex officio, stąd trudno traktować je jako procedurę zastępczą w stosunku do pozwolenia na budowę. Po drugie, polska procedura naprawcza objęta jest uprzednimi, bardzo wysokimi opłatami legalizacyjnymi, które są warunkiem sine qua non

\footnotetext{
13 Zob. motyw 58 wyroku C-215/06.
} 
zatwierdzenia projektu budowlanego ${ }^{14}$. Wszystko to prowadzi do wniosku, że polskie regulacje - dopuszczając w drodze wyjątku możliwość ustalenia środowiskowych uwarunkowań dla istniejącego przedsięwzięcia - nie tworzą w ten sposób instrumentów prawnych zachęcających do omijania przez inwestorów obowiązku poddania projektu inwestycji uprzedniej ocenie pod względem jej oddziaływania na środowisko w zakresie określonym dyrektywą 85/337/EWG.

W związku z przedstawionymi orzeczeniami i rozważaniami należy stwierdzić, że ustawowe sformułowanie, iż decyzję o środowiskowych uwarunkowaniach wydaje się dla „planowanego przedsięwzięcia" może budzić kontrowersje na tle przepisów o legalizacji przedsięwzięcia. Jest ono niefortunne, tym bardziej, że literalna interpretacja art. 71 ust. 1 ustawy ooś sugeruje, że ustawodawca dopuścił prowadzenie postępowania w sprawie środowiskowych uwarunkowań jedynie w odniesieniu do inwestycji nieistniejących. W zakresie interpretacji tego przepisu znaczącą rolę odegrało jednak orzecznictwo sądów administracyjnych, w którym przesądzano o konieczności uzyskania decyzji o środowiskowych uwarunkowaniach także dla inwestycji legalizowanych. Wydaje się także, że problem ten został rozstrzygnięty przez ustawodawcę przez wprowadzenie, wraz z ustawą ooś, art. 49 ust. 4a Prawa budowlanego nakazującego poprzedzenie decyzji wieńczących postępowanie legalizacyjne (decyzji o zatwierdzeniu projektu budowlanego i pozwoleniu na wznowienie robót, decyzji o zatwierdzeniu projektu budowlanego dla budowy zakończonej) oceną oddziaływania na środowisko w sytuacjach, jeżeli jest to wymagane przepisami ooś. Art. 49 ust. 4a Prawa budowlanego, jako regulacja zezwalająca na ocenę „następczą" może rodzić oczywiście pewne wątpliwości z punktu widzenia prewencyjnych celów dyrektywy 85/337/EWG. Uważamy jednak, że ten wyjątkowy przepis nie jest zachętą do omijania obowiązku oceny środowiskowej przedsięwzięć, stąd nie niweczy jej założeń.

14 art. 49 ust. 3 in fine Prawa budowlanego. 